\title{
Suitability of Saccharine for Preparation of Low Calorie Karadkheer
}

\author{
A.R. Walale, M.R. Patil and H.M. Gawande* \\ Department of Dairy Chemistry, College of Dairy Technology Warud (Pusad), \\ Dist- Yavatmal, (M.S.), India. 445204 \\ *Corresponding author
}

Keywords

Karadkheer,

Saccharine,

Artificial sweetener,

Low calorie

\section{Article Info}

Accepted:

12 February 2019

Available Online:

10 March 2019
Low calorie karadkheer was prepared by replacing 15\%, 30\%, 45\% and $60 \%$ sugar with saccharine and stored at $10{ }^{\circ} \mathrm{C}$. Karadkheer prepared with replacement of sugar up to $30 \%$ with saccharine was best accepted during storage which, possessed the same desirable sweetness and sensory attributes even after three days of storage. Storage studies revealed that saccharine sweetened karadkheer resembled the control karadkheer in retaining the sensory profile, but showed rise in acidity and microbial load. HPLC analysis of saccharine sweetened low calorie karadkheer samples showed no degradation of saccharine during entire period of storage.

\section{Introduction}

A variety of traditional dairy products are manufactured in India, most of which are region specific. Presently around 150 types of milk based sweet meats are available in the country. Traditional milk sweets are value added products and have great mass demand. About half of India's milk production is utilized in the preparation of different traditional dairy products. One such traditional cereal based popular dessert is kheer. Karadkheer a value added version of kheer, is a rural indigenous milk product prepared in Maharashtra state of India. It is prepared from milk, safflower milk prepared out of safflower (Carthamus tinctorius L.) extract, sugar and basmati rice. Karadkheer is a highly nutritious and health promoting product. Safflower extract used is a rich source of polyunsaturated fatty acids. It has higher content of linoleic acid and slightly lower content of linolenic acid. The potential therapeutic properties of karadkheer are; it is anticarcinogenic, antiatheroscleratic, growth promoting and lean body mass enhancing (Sarode, 2004). However, presence of high sugar in the product keeps away diabetic and health conscious people from consuming the product. 
Over last decade, demand for health foods in India has been fuelled by the increasing incidence of lifestyle-related diseases. In India, $13 \%$ females and $9 \%$ male are overweight (IIPS, 2007) and 62.4 million people lives with diabetes (Shetty, 2012). In India 65.1 million people of 20 to 79 year age group having diabetes in 2013 and it is projected to 109 million in year 2035 (International Diabetes Federation, 2014). Saccharine is the oldest sugar substitute and most widely used artificial sweetener in the world. It is 300 times sweeter than the sucrose. Inclusion of saccharine instead of sugar in food is believed to assist consumer in weight reduction, management of blood glucose in diabetes and pre-diabetic condition, reduction of dental caries, etc. The Government of India has permitted the use of saccharine in traditional dairy products. According to a Food Safety and Standards Regulations, 2011(FSSR, 2011), the use of artificial sweeteners has been allowed in food items as per the limits prescribed and under proper label declarations.

The degradation products of saccharine have been reported to be carcinogenic. Since the application of saccharine in indigenous dairy products is new, qualitative as well as quantitative information on sweetener's degradation in dairy system is required. Therefore, the present study has been undertaken to identify the most appropriate inclusion rate for saccharine to prepare an organoleptically acceptable karadkheer and to investigate the stability of saccharine in the product during storage.

\section{Materials and Methods}

\section{Sweetener and its standard degradation products}

Saccharine (Molychem, Thane, India) and its degradation product standard 2-sulfobenzoic acid (Sigma-Aldrich, Lovfs, MO, USA) were procured.

\section{Chemicals and Media}

Sulfuric acid, Iso-amyl alcohol, potassium sulphate, copper sulphate, sodium hydroxide, boric acid, hydrochloric acid, phenolphthalein indicator, standard buffer tablet of $\mathrm{pH} 4$ and $\mathrm{pH} 7$, Plate count agar, Potato dextrose agar (AR Grade, Himedia laboratories, Mumbai), sodium chloride, ethyl alcohol, diethyl ether, petroleum ether, zinc sulphate, potassium ferrocyanide, dipotassium hydrogen phosphate, potassium dihydrogen phosphate.

AR Grade, Molychem, Mumbai), acetonitrile, methanol, water (HPLC Grade, Molychem, Mumbai) Filter papers: Whatman No.42 (1.5 $\mu \mathrm{m}$. Carrez solution No.1, $3.6 \mathrm{~g}$ of potassium ferrocyanide dissolved in $100 \mathrm{ml} \mathrm{HPLC}$ grade water. Carrez solution No. 2, $7.2 \mathrm{~g}$ of zinc sulphate dissolved in $100 \mathrm{ml}$ HPLC grade water. Mobile phase: $0.02 \mathrm{M}$ phosphate buffer $\mathrm{pH}$ (5.0): acetonitrile (97:03).

\section{Standard solution of saccharine and degradation product}

Ten mg of sweetener and its degradation products were dissolved separately in $10 \mathrm{ml}$ of mobile phase to get stock standard solutions, with a concentration of $1 \mathrm{mg} / \mathrm{ml}$.

One hundred $\mu$ of stock standard solution were pipetted into separate $10 \mathrm{ml}$ volumetric flasks and volume was made up to mark with mobile phase to get standard solution of concentration $10 \mathrm{ng} / \mu \mathrm{l}$. (also $100 \mu \mathrm{l}$ from each stock standard solution (1 $\mathrm{mg} / \mathrm{ml})$ of saccharine and its degradation product, 2sulfobenzoic acid were pipetted into $10 \mathrm{ml}$ volumetric flasks and volume was made up to the mark with mobile phase to get mixture of each component as in the mixed solution of concentration of $10 \mathrm{ng} / \mu \mathrm{l})$. 


\section{Equipments}

Kelplus digestion and distillation assembly for protein estimation was supplied by Pelican Instruments, Chennai; Millipore type membrane filter (Z-37) by ASGI, India; High speed cooling centrifuge C-24 BL REMI by Remielectrotechnik Ltd., Mumbai and HPLC system by Dionex (UHPLC 3000 system, UV detector).

\section{Preparation of Karadkheer}

Fresh, white colour safflower seeds and high quality basmati rice were procured from local market. Low calorie karadkheer sweetened with saccharine was prepared using the method described by Sarode (2004), with slight modification. The preparation of kheer was carried out in two different phases. In the initial phase, the safflower milk was prepared from safflower seeds extract by method of Maske (1997) (Figure 1) and in later phase the kheer was prepared by blending the safflower milk with milk in 40:60 ratio (Figure 2). A control sample of karadkheer was also prepared using sugar and milk ('Rajhans' homogenized toned milk) procured from the local market and following the same method.

The method required sugar @ $9 \%$ of safflower milk and milk blend. Karadkheer prepared by using sugar @ $9 \%$ was considered as control and on the basis of sugar equivalence sugar was replaced at different levels with equivalent sweetness level of saccharine. Treatment and levels were as follows;

$\mathrm{T}_{1}=85 \%$ sugar + saccharine equivalent to $15 \%$ sugar.

$\mathrm{T}_{2}=70 \%$ sugar + saccharine equivalent to $30 \%$ sugar.

$\mathrm{T}_{3}=55 \%$ sugar + saccharine equivalent to $45 \%$ sugar.

$\mathrm{T}_{4}=40 \%$ sugar + saccharine equivalent to $60 \%$ sugar.
Saccharine was added at the end stage when karadkheer was cooled at room temperature. The product was homogenously mixed to ensure uniform distribution of sweetener in the product.

\section{Sample preparation and HPLC analysis}

Sample preparation procedure used for isolation (Figure 3) of sweetener from karadkheer was based on method of BSEN: 12856 (1999). Weights of saccharine sweetened samples for different treatments taken for sample preparation are given in Table 1. Calculated sample of low calorie karadkheer was taken in $100 \mathrm{ml}$ beaker and added with $50 \mathrm{ml}$ of HPLC grade water. Solution was transferred to a $100 \mathrm{ml}$ volumetric flask. Six ml of Carrez solution No. 1 was added and mixed followed by addition of $6 \mathrm{ml}$ of Carrez solution No. 2 to the solution.

The solution was shaken vigorously and allowed to stand at room temperature for 10 min. After dilution upto the mark with mobile phase, filtration was carried out using a Whatman No. 1 filter paper through sintered funnel. Filtrate was centrifuged to clear supernatant and was used for HPLC analysis during storage. HPLC analysis of reference standards of saccharine, its degradation product and sample isolates from karadkheer were performed under standardized conditions. Reverse phase HPLC analysis were performed over $\mathrm{C}_{18}$ column at $\mathrm{UV}$ detector wavelength $200 \mathrm{~nm}$. Mobile phase was used at a flow rate of $1 \mathrm{ml} / \mathrm{min}$ with run time of $30 \mathrm{~min}$.

\section{Chemical composition of karadkheer}

Saccharine sweetened karadkheer and control sample composition was analyzed for moisture and fat (IS: SP Part XI, 1981), total protein, ash and $\mathrm{pH}$ (AOAC, 1990). 


\section{Storage and analysis of karadkheer}

Control and artificially sweetened samples of karadkheer were packed in polypropylene cups and stored at refrigerated temperature (10 $\left.{ }^{\circ} \mathrm{C}\right)$. The samples were analyzed from first to third day of storage for titratable acidity, $\mathrm{pH}$, Standard Plate Count and Yeast and Mold Count using standard method (IS: SP Part XI, 1981). Incubation of the plates was carried out at $37{ }^{\circ} \mathrm{C}$ for $48 \mathrm{hrs}$ and $30{ }^{\circ} \mathrm{C}$ for $3-5$ days respectively.

\section{Sensory evaluation}

The samples of karadkheer were evaluated for the sweetness, colour and appearance, body \& texture and overall acceptability by a panel of 5 judges from the faculty of College of Dairy Technology, Warud (Pusad) using 9-point hedonic scale score card (Amerine et al., 1965).

\section{Statistical analysis}

In all experiments, one-way analysis of variance (ANOVA) with a subsequent least significant difference (LSD) test was applied for multiple sample comparison. This was done to test for any significant differences $(\mathrm{P}<0.05)$ in the mean values of all the treatments as described by Snedecor and Cochran (1989). Data from three replications of each experiment were analyzed for statistical analysis.

\section{Results and Discussion}

\section{Selection of method for production of low calorie karadkheer}

Two different methods suggested for the preparation of karadkheer by Narwade (1997) and Sarode (2004) were compared on sensory ground (Table 2) to select the method for preparation of low calorie carrot karadkheer.
Sensory evaluation revealed that karadkheer prepared by the method of Sarode (2004) was superior to the method of Narwade (1997) against all sensory attributes. Concentration of safflower milk greatly influences the acceptability of the product due to its flavor, color, body and texture. Proper cooking of rice in milk improved the taste and texture whereas, milk solid gave desired richness and flavor to the product. Replacement of the sugar with artificial sweetener is possible in method described by Sarode (2004) which facilitates addition of sweetener at the end stage of heating treatment to prevent possible heat damage to the artificial sweetener. Hence, the method by Sarode (2004) was selected for the preparation of karadkheer.

Effect of saccharine on chemical composition of karadkheer

Replacement of $15 \%, 30 \%, 45 \%$ and $60 \%$ of the total sugar in karadkheer with equivalent quantity of saccharine resulted into non significant difference $(\mathrm{P}<0.05)$ in fat, protein, ash and $\mathrm{pH}$ with respect to control (Table 3). However, samples sweetened with saccharine noticed slight increase in moisture content with increase in saccharine replacement of sugar in respect to control. The results for compositional parameters of saccharine sweetened karadkheer were in accordance with results reported by Sarode (2004) for karadkheer, De et al., (1976) for kheer prepared without safflower extract and Mathur et al., (1985) for kheer prepared with 10\% basmati rice and $15 \%$ sugar.

\section{Storage related changes in saccharine sweetened karadkheer}

\section{Sensory profile}

Sensory analysis (Table 4) revealed that $T_{2}$ was best accepted among all the treatments studied during storage. The sweetness scores 
of all the treatments and control were constant during storage. The score of $\mathrm{T}_{2}$ was superior to remaining treatments as well as control. $\mathrm{T}_{3}$ and $\mathrm{T}_{4}$ treatments scored very less as the product was not accepted by judges. The reduction in score was mainly due to development of bitter taste with increase in concentration of saccharine. Vairagade et al., (2016) reported the similar results in case of carrot halwa sweetened with saccharine. The colour scores of all the treatments were reduced during storage and as storage period increased the score reduced significantly. Among all the samples $\mathrm{T}_{4}$ sample had slightly more off-white color and hence was less accepted and got lower score. The appearance score of all the treatments including control were non-significant up to the second day of storage however, significant difference was observed at third day of storage. Control and $\mathrm{T}_{2}$ samples were acceptable up to the third day of storage, but there was significant reduction in score than fresh sample. The body and texture score of control was highest and at par with $T_{1}$ and $T_{2}$ samples. Samples $T_{3}$ and $T_{4}$ were significantly lower $(\mathrm{P}<0.05)$ from control, $\mathrm{T}_{1}$ and $\mathrm{T}_{2}$. As artificial sweetener had insufficient water binding capacity, it might have resulted in slightly low score for the samples having more amount of artificial sweetener in the sample. The $\mathrm{T}_{2}$ sample was best accepted and at par with control for body and texture scores during storage. The flavour scores of sample $T_{3}$ and $T_{4}$ were significantly different $(\mathrm{P}<0.05)$ from control, $\mathrm{T}_{1}$ and $\mathrm{T}_{2}$. Control and $\mathrm{T}_{2}$ samples were acceptable up to the third day of storage, but there was significant reduction in score than fresh sample. The overall acceptability score of the $\mathrm{T}_{2}$ was highest among all the treatments and resembled control upto the end of storage. The $\mathrm{T}_{1}$ sample also showed the acceptable score up to third day but scored lower than control and $T_{2}$. While the scores for the $T_{3}$ and $T_{4}$ sample were significantly lower from initial day up to the last day of storage. It is evident that the sensory scores of $\mathrm{T}_{2}$ for all sensory attributes were at par with control and more than control in some cases, which indicates its acceptability on the sensory ground. It was also observed that the rate of decline in the sensory scores of $\mathrm{T}_{2}$ was more than that of control during the storage. Similar results were observed with saccharine sweetened burfi and kalakand (Kumar, 2006) and carrot halwa (Vairagade et al., 2016) during storage.

Table.1 Weight of saccharine sweetened karadkheer for HPLC analysis

\begin{tabular}{|c|c|}
\hline Treatment & Saccharine sweetened samples $(\mathbf{g})$ \\
\hline $\mathbf{T}_{\mathbf{1}}$ & 43.06 \\
\hline $\mathbf{T}_{\mathbf{2}}$ & 21.26 \\
\hline $\mathbf{T}_{\mathbf{3}}$ & 13.99 \\
\hline $\mathbf{T}_{\mathbf{4}}$ & 10.36 \\
\hline
\end{tabular}

Table.2 Sensory scores of karadkheer prepared by different methods

\begin{tabular}{|c|c|c|}
\hline \multirow{2}{*}{ Parameters } & \multicolumn{2}{|c|}{ Methods for selection of Recipe } \\
\cline { 2 - 3 } & Narwade (1997) & Sarode (2004) \\
\hline Appearance and colour & $7.13 \pm 0.52$ & $7.47 \pm 0.52$ \\
\hline Flavour & $6.60 \pm 0.06$ & $6.6 \pm 0.28$ \\
\hline Body and texture & $6.87 \pm 0.83$ & $7.13 \pm 0.83$ \\
\hline Overall acceptability & $6.60 \pm 0.83$ & $7.60 \pm 0.74$ \\
\hline
\end{tabular}

All scores are average of three replications. Data are presented as Means \pm S.D 
Table.3 Chemical composition of saccharine sweetened karadkheer

\begin{tabular}{|c|c|c|c|c|c|}
\hline Parameters & Moisture (\%) & Fat (\%) & Protein $(\%)$ & Ash (\%) & pH \\
\hline Control & $59.86 \pm 3.50^{c}$ & $7.75 \pm 0.21^{\mathrm{a}}$ & $5.53 \pm 0.10^{b}$ & $0.78 \pm 0.01^{\mathrm{a}}$ & $5.35 \pm 0.06^{a}$ \\
\hline $\mathbf{T}_{1}$ & $62.38 \pm 3.65^{b c}$ & $7.85 \pm 0.13^{\mathrm{a}}$ & $5.54 \pm 0.08^{b}$ & $0.83 \pm 0.08^{\mathrm{a}}$ & $5.29 \pm 0.03^{a}$ \\
\hline $\mathbf{T}_{2}$ & $64.84 \pm 1.94^{\mathrm{ab}}$ & $7.86 \pm 0.21^{\mathrm{a}}$ & $5.57 \pm 0.02^{b}$ & $0.85 \pm 0.03^{\mathrm{a}}$ & $5.28 \pm 0.05^{\mathrm{a}}$ \\
\hline $\mathbf{T}_{3}$ & $66.71 \pm 1.25^{\mathrm{ab}}$ & $7.93 \pm 0.21^{\mathrm{a}}$ & $5.63 \pm 0.02^{b}$ & $0.83 \pm 0.08^{\mathrm{a}}$ & $5.30 \pm 0.08^{\mathrm{a}}$ \\
\hline $\mathbf{T}_{4}$ & $68.85 \pm 2.16^{a}$ & $7.83 \pm 0.18^{a}$ & $5.77 \pm 0.02^{a}$ & $0.88 \pm 0.04^{a}$ & $5.23 \pm 0.12^{\mathrm{a}}$ \\
\hline
\end{tabular}

All scores are average of three replications. The superscripts a, b, c and $\mathrm{d}$ in each column indicate significantly different means at $\mathrm{P}<0.05$. Data are presented as Means \pm S.D

Table.4 Changes in quality of saccharine sweetened karadkheer during storage at $10{ }^{\circ} \mathrm{C}$

\begin{tabular}{|c|c|c|c|}
\hline \multirow{2}{*}{$\begin{array}{l}\text { Particulars of } \\
\text { Karadkheer }\end{array}$} & \multicolumn{3}{|c|}{ Storage Days } \\
\hline & 1 & 2 & 3 \\
\hline \multicolumn{4}{|l|}{ Sensory Attributes } \\
\hline \multicolumn{4}{|l|}{ Sweetness } \\
\hline Control & $7.47 \pm 0.74^{\mathrm{a}}$ & $7.20 \pm 0.86^{\mathrm{a}}$ & $7.40 \pm 0.74^{\mathrm{a}}$ \\
\hline $\mathbf{T}_{1}$ & $7.53 \pm 0.74^{\mathrm{a}}$ & $7.53 \pm 0.99^{\mathrm{a}}$ & $7.47 \pm 0.83^{\mathrm{a}}$ \\
\hline $\mathbf{T}_{2}$ & $7.60 \pm 0.63^{\mathrm{a}}$ & $7.47 \pm 0.99^{\mathrm{a}}$ & $7.50 \pm 0.61^{\mathrm{a}}$ \\
\hline$T_{3}$ & $6.73 \pm 0.88^{b}$ & $6.47 \pm 0.99^{\mathrm{b}}$ & $6.73 \pm 0.80^{b}$ \\
\hline $\mathbf{T}_{4}$ & $6.27 \pm 0.70^{b}$ & $6.27 \pm 1.03^{b}$ & $6.33 \pm 0.72^{b}$ \\
\hline \multicolumn{4}{|l|}{ Color } \\
\hline Control & $7.40 \pm 0.63^{\mathrm{a}}$ & $7.33 \pm 0.49^{\mathrm{a}}$ & $7.47 \pm 0.64^{\mathrm{a}}$ \\
\hline $\mathbf{T}_{1}$ & $7.20 \pm 0.56^{\mathrm{a}}$ & $7.20 \pm 0.56^{\mathrm{a}}$ & $7.33 \pm 0.49^{\mathrm{a}}$ \\
\hline $\mathbf{T}_{2}$ & $7.40 \pm 0.74^{\mathrm{a}}$ & $7.53 \pm 0.64^{\mathrm{a}}$ & $7.53 \pm 0.64^{\mathrm{a}}$ \\
\hline $\mathbf{T}_{3}$ & $7.20 \pm 0.68^{\mathrm{a}}$ & $7.13 \pm 0.64^{\mathrm{a}}$ & $7.33 \pm 0.62^{\mathrm{a}}$ \\
\hline $\mathbf{T}_{4}$ & $7.00 \pm 0.65^{\mathrm{a}}$ & $7.13 \pm 0.64^{\mathrm{a}}$ & $7.07 \pm 0.59^{\mathrm{a}}$ \\
\hline \multicolumn{4}{|l|}{ Appearance } \\
\hline Control & $7.53 \pm 0.74^{\mathrm{a}}$ & $7.33 \pm 0.90^{\mathrm{a}}$ & $7.60 \pm 0.63^{\mathrm{a}}$ \\
\hline $\mathbf{T}_{1}$ & $7.13 \pm 0.74^{\mathrm{a}}$ & $7.20 \pm 0.77^{\mathrm{a}}$ & $7.20 \pm 0.68^{\mathrm{ab}}$ \\
\hline $\mathbf{T}_{2}$ & $7.47 \pm 0.74^{\mathrm{a}}$ & $7.27 \pm 0.80^{\mathrm{a}}$ & $7.53 \pm 0.64^{\mathrm{a}}$ \\
\hline $\mathbf{T}_{3}$ & $7.20 \pm 0.77^{\mathrm{a}}$ & $6.87 \pm 0.74^{\mathrm{a}}$ & $7.27 \pm 0.70^{\mathrm{ab}}$ \\
\hline $\mathbf{T}_{4}$ & $6.87 \pm 0.83^{\mathrm{a}}$ & $6.80 \pm 0.94^{\mathrm{a}}$ & $6.80 \pm 0.77^{b}$ \\
\hline \multicolumn{4}{|l|}{ Body and texture } \\
\hline Control & $7.27 \pm 0.70^{\mathrm{a}}$ & $7.53 \pm 0.64^{\mathrm{a}}$ & $7.47 \pm 0.64^{\mathrm{a}}$ \\
\hline $\mathbf{T}_{1}$ & $7.20 \pm 0.77^{\mathrm{a}}$ & $7.33 \pm 0.72^{\mathrm{ab}}$ & $7.33 \pm 0.72^{\mathrm{a}}$ \\
\hline $\mathbf{T}_{2}$ & $7.33 \pm 0.82^{\mathrm{a}}$ & $7.33 \pm 0.72^{\mathrm{ab}}$ & $7.47 \pm 0.74^{\mathrm{a}}$ \\
\hline $\mathbf{T}_{3}$ & $6.87 \pm 0.99^{\mathrm{a}}$ & $6.80 \pm 0.94^{\mathrm{bc}}$ & $6.93 \pm 1.03^{\mathrm{ab}}$ \\
\hline$T_{4}$ & $6.73 \pm 0.96^{\mathrm{a}}$ & $6.67 \pm 1.05^{\mathrm{c}}$ & $6.67 \pm 1.05^{\mathrm{b}}$ \\
\hline \multicolumn{4}{|l|}{ Flavor } \\
\hline Control & $7.47 \pm 0.64^{\mathrm{a}}$ & $7.40 \pm 0.76^{\mathrm{a}}$ & $7.34 \pm 0.64^{\mathrm{a}}$ \\
\hline $\mathbf{T}_{1}$ & $7.33 \pm 0.62^{\mathrm{a}}$ & $7.33 \pm 0.76^{\mathrm{ab}}$ & $7.29 \pm 0.72^{\mathrm{a}}$ \\
\hline $\mathbf{T}_{2}$ & $7.47 \pm 0.52^{\mathrm{a}}$ & $7.33 \pm 0.83^{\mathrm{ab}}$ & $7.27 \pm 0.52^{\mathrm{a}}$ \\
\hline
\end{tabular}




\begin{tabular}{|c|c|c|c|}
\hline $\mathbf{T}_{3}$ & $7.07 \pm 0.70^{\mathrm{ab}}$ & $6.80 \pm 0.89^{\mathrm{bc}}$ & $6.75 \pm 0.70^{\mathrm{ab}}$ \\
\hline $\mathbf{T}_{4}$ & $6.73 \pm 0.80^{b}$ & $6.47 \pm 0.92^{c}$ & $6.60 \pm 0.74^{b}$ \\
\hline \multicolumn{4}{|c|}{ Overall Acceptability } \\
\hline Control & $7.47 \pm 0.52^{\mathrm{ab}}$ & $7.33 \pm 0.72^{\mathrm{a}}$ & $7.40 \pm 0.51^{\mathrm{ab}}$ \\
\hline$T_{1}$ & $7.07 \pm 0.80^{\mathrm{bc}}$ & $7.47 \pm 0.83^{\mathrm{a}}$ & $7.20 \pm 0.77^{b}$ \\
\hline $\mathbf{T}_{2}$ & $7.67 \pm 0.82^{\mathrm{a}}$ & $7.67 \pm 0.82^{\mathrm{a}}$ & $7.87 \pm 0.64^{\mathrm{a}}$ \\
\hline $\mathbf{T}_{3}$ & $6.73 \pm 0.94^{\mathrm{c}}$ & $6.47 \pm 0.90^{b}$ & $6.67 \pm 0.88^{c}$ \\
\hline $\mathbf{T}_{4}$ & $6.60 \pm 0.63^{c}$ & $6.40 \pm 0.83^{b}$ & $6.53 \pm 0.64^{\mathrm{c}}$ \\
\hline \multicolumn{4}{|c|}{ Physicochemical Attributes } \\
\hline \multicolumn{4}{|c|}{ pH } \\
\hline Control & $5.35 \pm 0.06^{\mathrm{a}}$ & $5.33 \pm 0.06^{\mathrm{a}}$ & $5.31 \pm 0.07^{\mathrm{a}}$ \\
\hline $\mathbf{T}_{1}$ & $5.29 \pm 0.03^{\mathrm{a}}$ & $5.28 \pm 0.02^{\mathrm{a}}$ & $5.26 \pm 0.03^{\mathrm{a}}$ \\
\hline $\mathbf{T}_{2}$ & $5.27 \pm 0.05^{\mathrm{a}}$ & $5.26 \pm 0.05^{\mathrm{a}}$ & $5.23 \pm 0.07^{\mathrm{a}}$ \\
\hline $\mathbf{T}_{3}$ & $5.30 \pm 0.08^{\mathrm{a}}$ & $5.38 \pm 0.14^{\mathrm{a}}$ & $5.33 \pm 0.14^{\mathrm{a}}$ \\
\hline $\mathbf{T}_{4}$ & $5.23 \pm 0.12^{\mathrm{a}}$ & $5.19 \pm 0.17^{\mathrm{a}}$ & $5.14 \pm 0.17^{\mathrm{a}}$ \\
\hline \multicolumn{4}{|l|}{ Acidity (\% LA) } \\
\hline Control & $0.066 \pm 0.002^{\mathrm{a}}$ & $0.073 \pm 0.003^{\mathrm{a}}$ & $0.085 \pm 0.002^{\mathrm{a}}$ \\
\hline $\mathbf{T}_{1}$ & $0.067 \pm 0.002^{\mathrm{a}}$ & $0.074 \pm 0.001^{\mathrm{a}}$ & $0.081 \pm 0.001^{\mathrm{a}}$ \\
\hline $\mathbf{T}_{2}$ & $0.065 \pm 0.002^{\mathrm{a}}$ & $0.079 \pm 0.002^{\mathrm{a}}$ & $0.086 \pm 0.001^{\mathrm{a}}$ \\
\hline $\mathbf{T}_{3}$ & $0.065 \pm 0.004^{\mathrm{a}}$ & $0.071 \pm 0.002^{\mathrm{a}}$ & $0.085 \pm 0.003^{\mathrm{a}}$ \\
\hline $\mathbf{T}_{4}$ & $0.068 \pm 0.006^{\mathrm{a}}$ & $0.076 \pm 0.003^{\mathrm{a}}$ & $0.091 \pm 0.008^{\mathrm{a}}$ \\
\hline \multicolumn{4}{|c|}{ Microbiological Quality } \\
\hline \multicolumn{4}{|l|}{ SPC (log cfu/g) } \\
\hline Control & $1.97 \times 10^{4} \pm 0.76^{b}$ & $2.51 \times 10^{4} \pm 0.14^{\mathrm{d}}$ & $2.55 \times 10^{4} \pm 0.65^{\mathrm{c}}$ \\
\hline$T_{1}$ & $2.84 \times 10^{4} \pm 0.80^{\mathrm{ab}}$ & $3.24 \times 10^{4} \pm 0.09^{c}$ & $3.29 \times 10^{4} \pm 0.23^{\mathrm{b}}$ \\
\hline $\mathbf{T}_{2}$ & $2.98 \times 10^{4} \pm 0.31^{\mathrm{ab}}$ & $3.71 \times 10^{4} \pm 0.30^{\mathrm{bc}}$ & $3.73 \times 10^{4} \pm 0.24^{\mathrm{ab}}$ \\
\hline $\mathbf{T}_{3}$ & $3.63 \times 10^{4} \pm 0.25^{\mathrm{a}}$ & $4.22 \times 10^{4} \pm 0.29^{\mathrm{ab}}$ & $3.87 \times 10^{4} \pm 0.17^{\mathrm{ab}}$ \\
\hline $\mathbf{T}_{4}$ & $3.70 \times 10^{4} \pm 0.52^{\mathrm{a}}$ & $4.56 \times 10^{4} \pm 0.43^{\mathrm{a}}$ & $4.05 \times 10^{4} \pm 0.29^{\mathrm{a}}$ \\
\hline \multicolumn{4}{|c|}{ Yeast \& Mold Count (log cfu/g) } \\
\hline Control & $0.30 \times 10^{4} \pm 0.18^{\mathrm{a}}$ & $0.20 \times 10^{4} \pm 0.05^{\mathrm{a}}$ & $0.62 \times 10^{4} \pm 0.35^{\mathrm{a}}$ \\
\hline$T_{1}$ & $0.12 \times 10^{4} \pm 0.02^{b}$ & $0.16 \times 10^{4} \pm 0.02^{b}$ & $0.28 \times 10^{4} \pm 0.12^{b}$ \\
\hline $\mathbf{T}_{2}$ & $0.10 \times 10^{4} \pm 0.01^{c}$ & $0.16 \times 10^{4} \pm 0.04^{b}$ & $0.21 \times 10^{4} \pm 0.05^{c}$ \\
\hline $\mathbf{T}_{3}$ & $0.08 \times 10^{4} \pm 0.05^{d}$ & $0.15 \times 10^{4} \pm 0.04^{c}$ & $0.20 \times 10^{4} \pm 0.09^{d}$ \\
\hline $\mathbf{T}_{4}$ & $0.06 \times 10^{4} \pm 0.04^{\mathrm{e}}$ & $0.13 \times 10^{4} \pm 0.02^{d}$ & $0.15 \times 10^{4} \pm 0.04^{e}$ \\
\hline
\end{tabular}

All scores are average of three replications. The superscripts $a, b, c$ and $d$ in each column of each attribute indicate significantly different means at $\mathrm{P}<0.05$. Data are presented as Means \pm S.D 
Fig.1 Flow chart for preparation of safflower milk
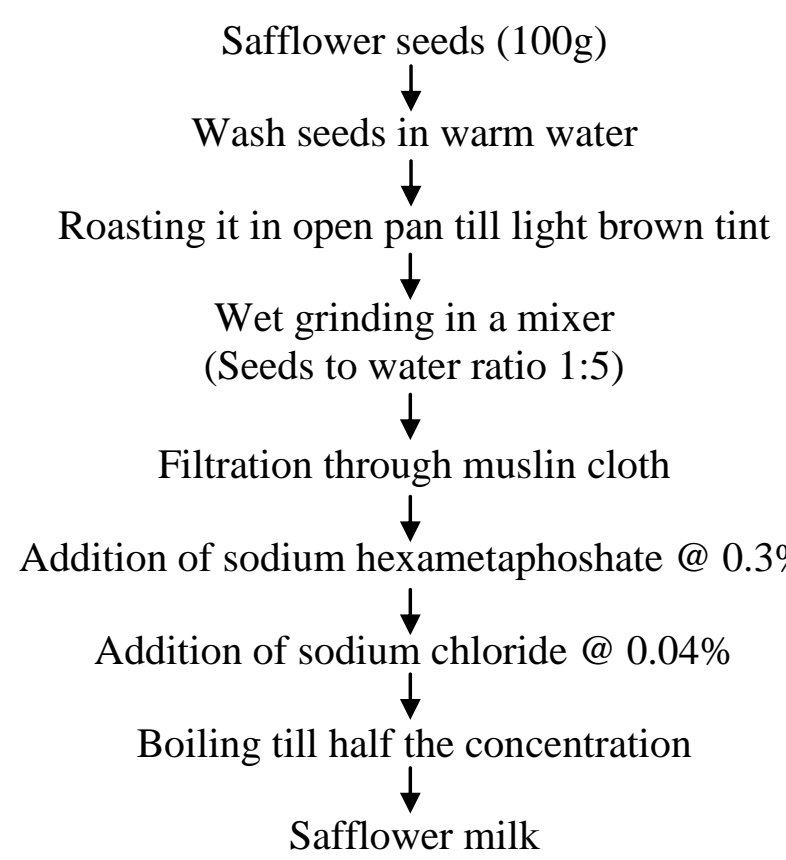

Fig.2 Flow diagram for preparation of low calorie Karadkheer

Milk ("Rajhans" homogenized toned milk)

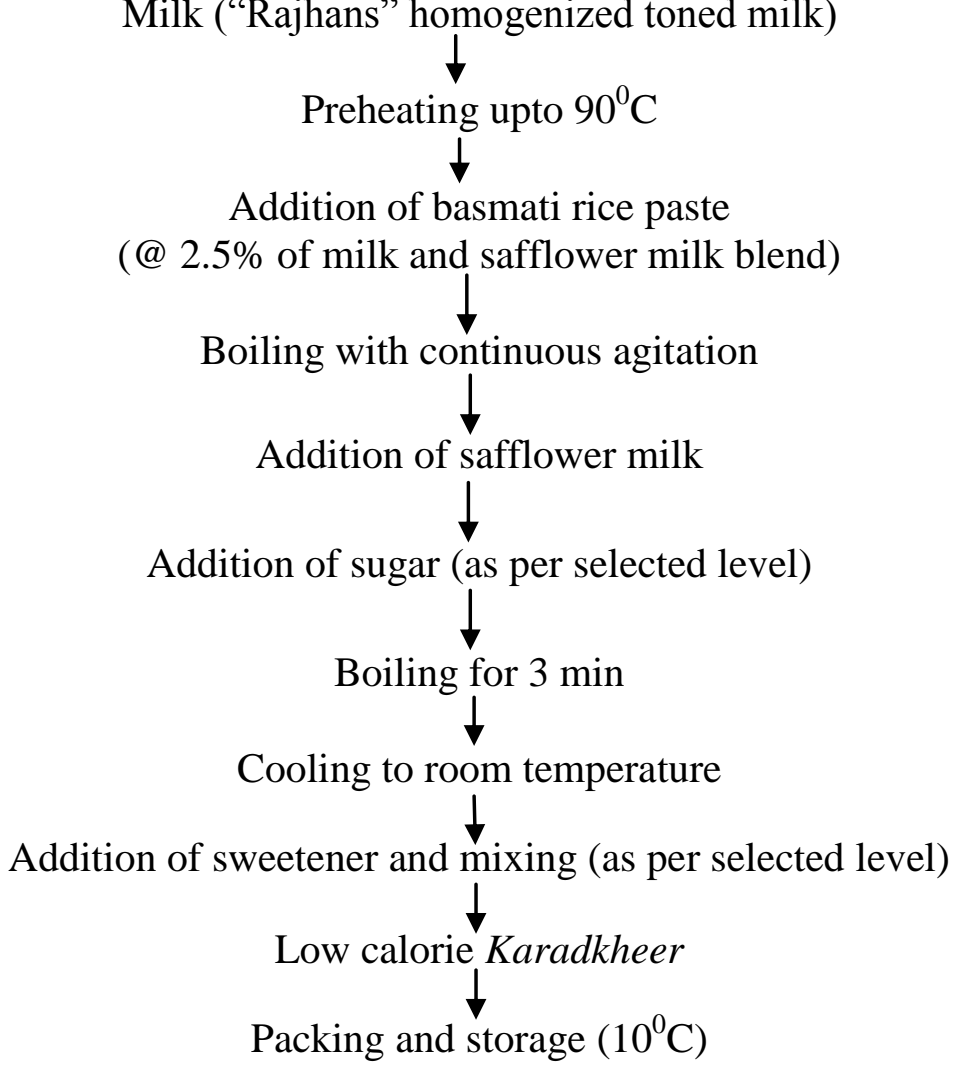


Fig.3 Flow chart for isolation of saccharine from Karadkheer

Low calorie Karadkheer in $100 \mathrm{ml}$ beaker

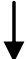

Dilution with HPLC grade water $(50 \mathrm{ml}) 40{ }^{\circ} \mathrm{C}$

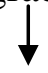

Carrez Clarification (6 ml Carrez solution No.1 + $6 \mathrm{ml}$ Carrez solution No.2)

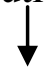

Dilution up to the mark (100 $\mathrm{ml})$

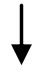

Filtration (Whatman No.1 filter paper)

$\downarrow$

Centrifugation of filtrate to get clear supernatant for HPLC (10000 rpm)
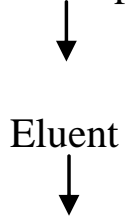

HPLC analysis

Fig.4 HPLC chromatogram of saccharine and its degradation product standards

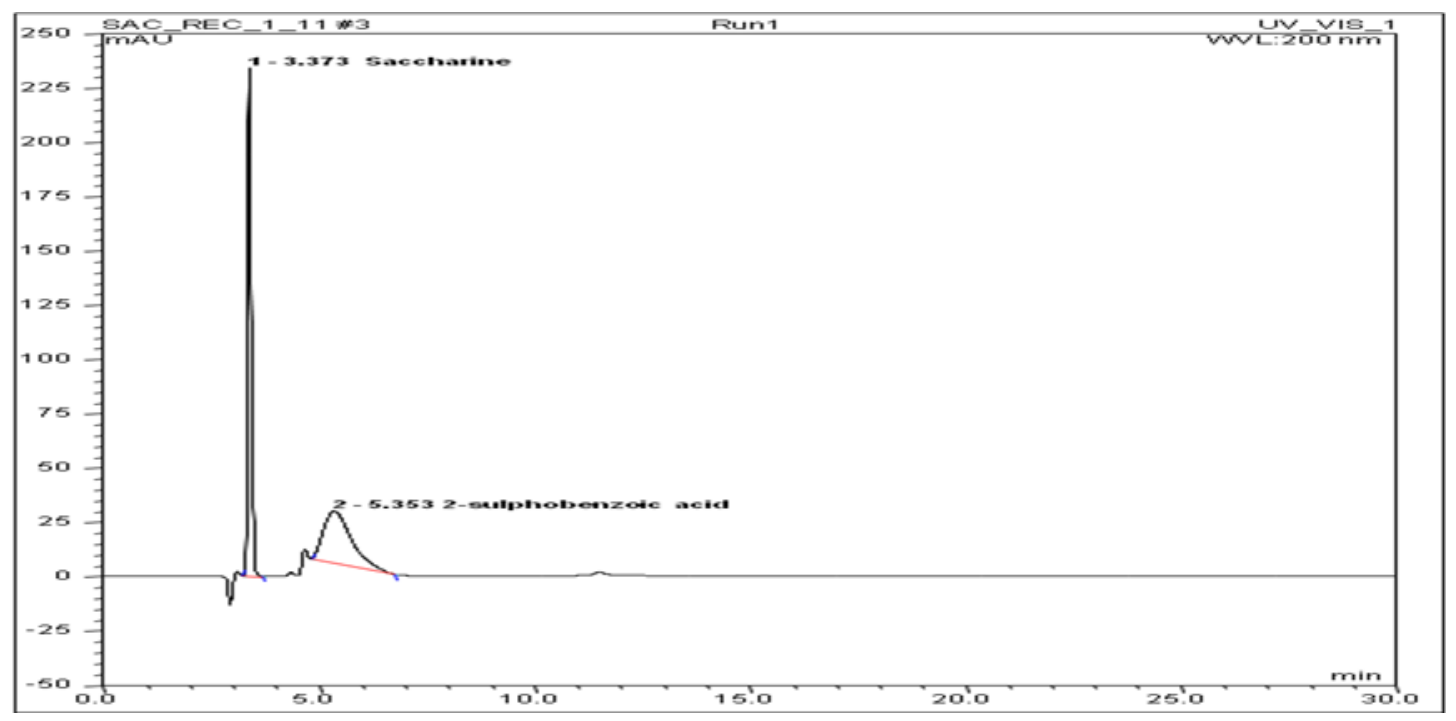


Fig.5 HPLC chromatograms of sample isolates of saccharine sweetened Karadkheer during 1st day of storage

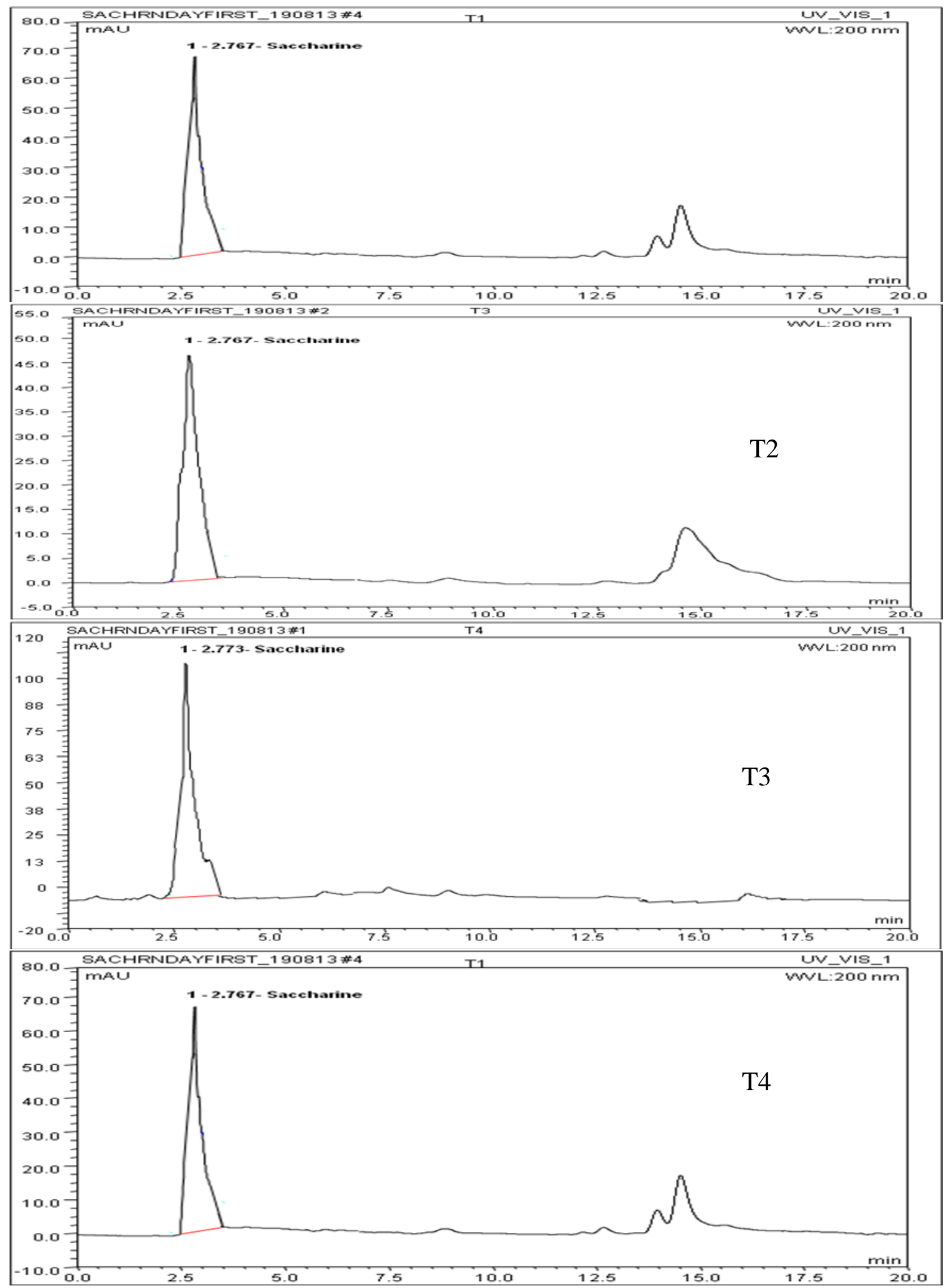


Fig.6 HPLC chromatograms of sample isolates of saccharine sweetened Karadkheer during 2nd day of storage

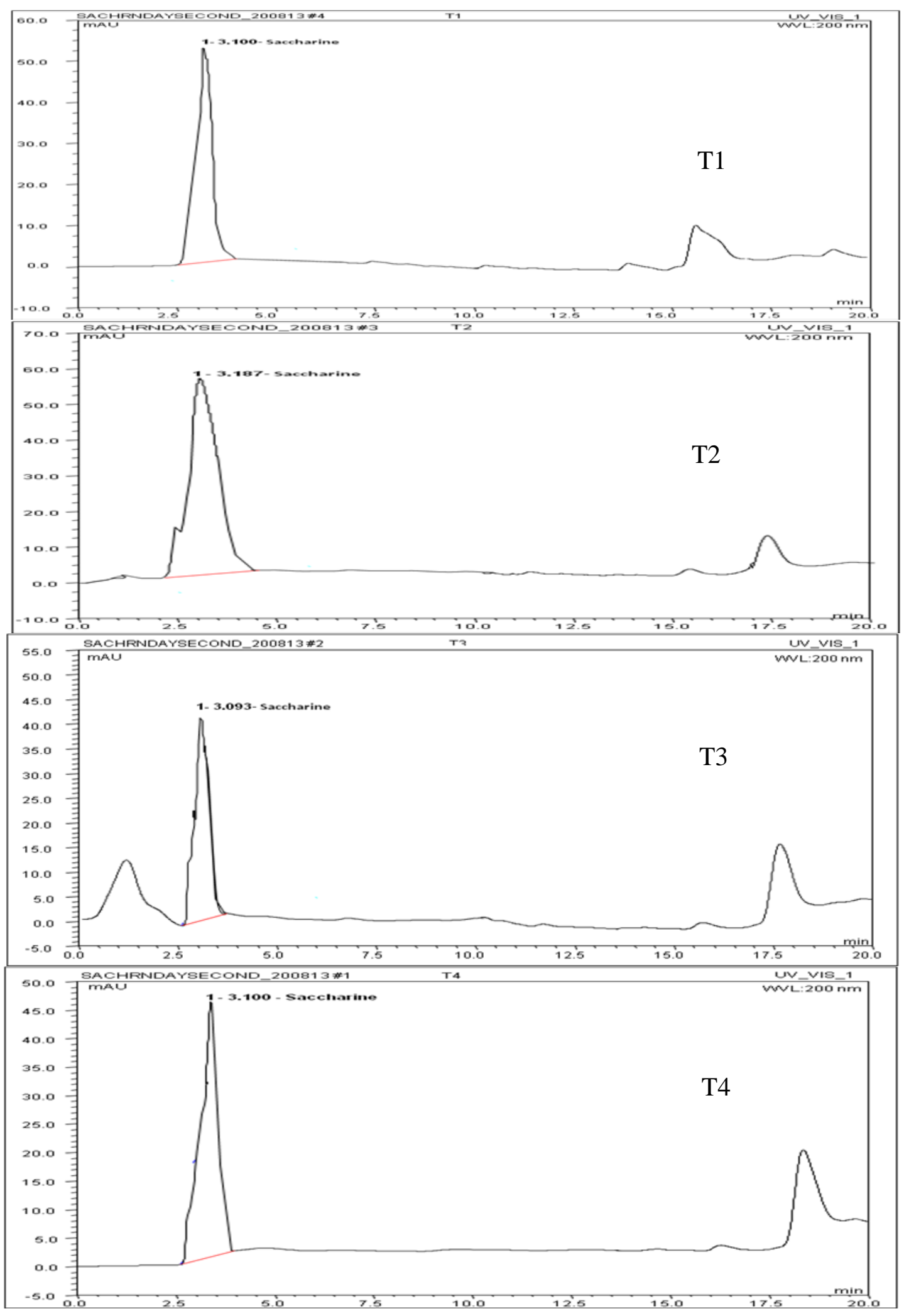


Fig.7 HPLC chromatograms of sample isolates of saccharine Karadkheer during 3rd day of storage

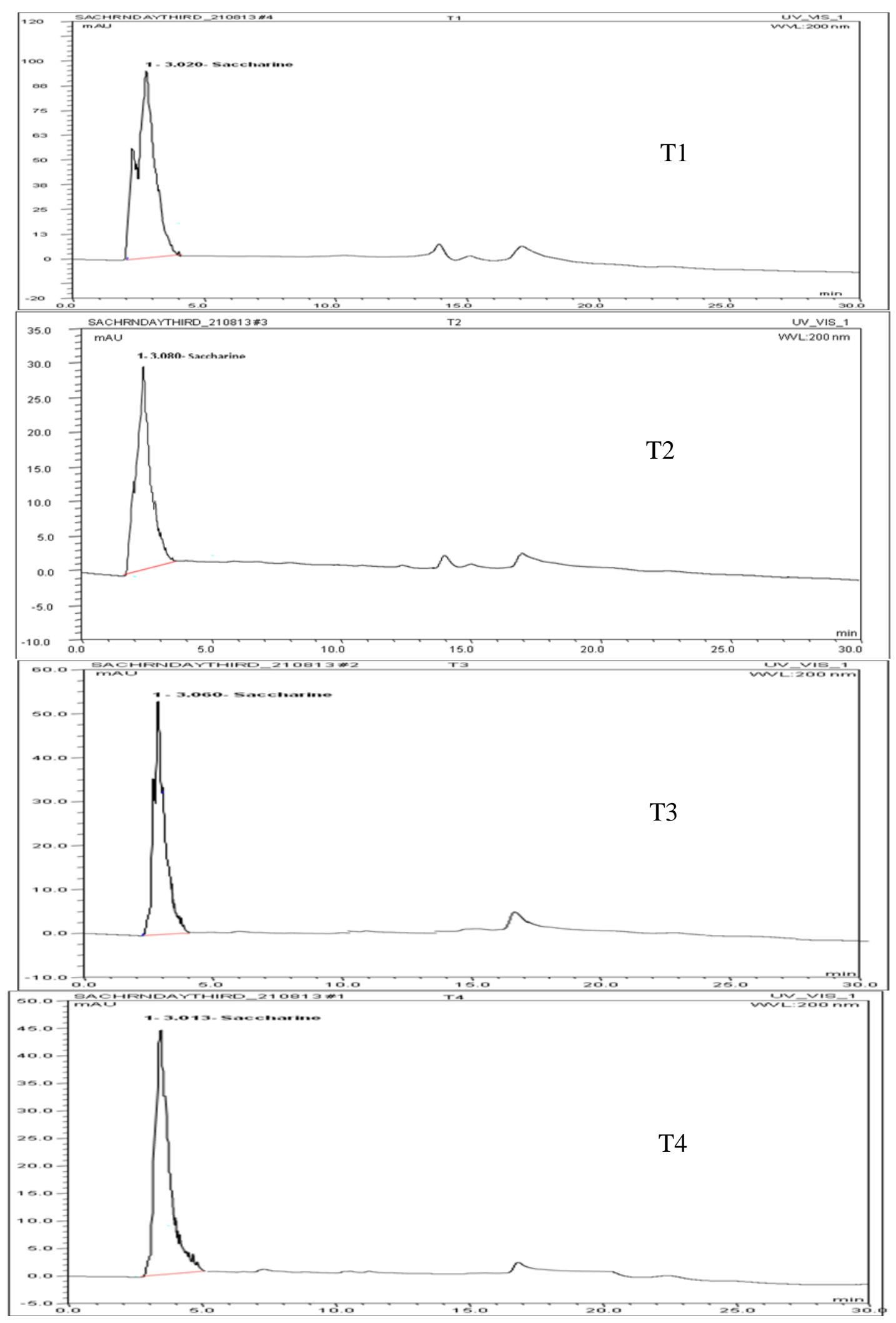




\section{Titratable acidity and pH}

Low calorie karadkheer sweetened with saccharine and control observed slight but statistically non significant $(\mathrm{P}>0.05)$ decrease in $\mathrm{pH}$ during storage (Table 4). Similar results were observed by Kumar (2006) and Vairagade et al., (2016) for $\mathrm{pH}$ of saccharine sweetened burfi and carrot halwa respectively. Continuous increase in titratable acidity was noted in both control as well as saccharine sweetened karadkheer samples during the storage (Table 4). It was observed that samples containing more quantity of sweetener had more titratable acidity but this effect was not statistically significant.

\section{Microbiological examination}

Standard plate counts and Yeast and mold counts increased for saccharine sweetened products and control during storage. Standard plate counts were higher $(\mathrm{P}<0.05)$ in saccharine sweetened product than their corresponding control throughout the storage period (Table 4). The incorporation of saccharine reduces concentration of sugar, lowering the preservation effect of sugar, ultimately lead to higher microbial counts. The results observed are in accordance with standard plate count observed for saccharine sweetened flavoured milk (Arora et al., 2008) and carrot halwa (Vairagade et al., 2016). However, Yeast and mold counts of saccharine sweetened low calorie karadkheer samples were lower as compared to control samples (Table 3). Presence of higher sugar levels ultimately lead to significant linear rise $(\mathrm{P}<0.05)$ in Yeast and mold counts in control and all the treatments.

\section{Stability of saccharine}

Saccharine and 2-sulphobenzoic acid gave $\lambda_{\max }$ at $200 \mathrm{~nm}$. Figure 4 represents HPLC chromatogram of these two components at
$200 \mathrm{~nm}$ under the standardized analytical conditions.

\section{Stability of saccharine in karadkheer during storage}

HPLC chromatograms obtained during first to third days of storage for saccharine sweetened karadkheer for all the treatments are represented in figure 5, 6 and 7 respectively. No peak other than saccharine can be seen in these chromatograms, establishing that saccharine was not degraded up to the third day of storage in all samples. This established that saccharine was stable in karadkheer during storage in all samples. Results observed were in accordance with saccharine sweetened burfi (Kumar, 2006), flavoured milk (Arora et al., 2008) and carrot halwa (Vairagade et al., 2016).

In conclusion, sensory profile during storage study at $10^{\circ} \mathrm{C}$ revealed that saccharinesweetened karadkheer resembled the control karadkheer in retaining sweetness. Replacement of sugar level up to $30 \%$ was found optimum for the saccharine sweetened karadkheer on the basis of sensory evaluation. However, saccharine-sweetened karadkheer ranked lower than the control in sensory profile, acidity and microbial load. Highperformance liquid chromatography analytical conditions were standardized for the separation of saccharine and its degradation product 2-sulphobenzoic acid over a $\mathrm{C}_{18}$ column at UV $200 \mathrm{~nm}$. HPLC analysis of saccharine sweetened karadkheer samples showed no degradation upto the third day of storage in all samples.

\section{References}

Amerine, M. A., Pangborn, R. M., and Roessler, E. B., 1965. Principles of Sensory Evaluation of Food. Academic Press, New York. 
AOAC International, 1997. Official methods of analysis of AOAC International, $16^{\text {th }}$ edition, North Fredrick Avenue, Gaithersburg, Maryland, USA.

Arora, S., Narendra, K., Gawande, H., Yarrakula, S., Sharma, V., Wadhawa, B. K., George, V., and Sharma, G. S., 2008. Stability of artificial sweeteners saccharine, acesulfame-K and aspartame in flavoured milk. Indian Journal of Dairy Science. 61(5): 334341.

BSEN:12856, 1999. Foodstuffs Determination of acesulfame-K, aspartame and saccharin - High performance liquid chromatographic method. Cited by Wood, R.; Foster, L. and Key, P., In: Analytical methods for food additive, Woodhead Publishing Ltd., CRC Press, 2004, pp. 231-252.

De, S., Thompkinson, D. K., Gahlot, D. P., and Mathur, O. N., 1976. Studies on method of preparation and preservation of kheer. Indian Journal of Dairy Science. 29(4): 316-318.

FSSR, 2011. Food Safety and Standards Act, Rules and Regulations. Akalank Publications, New Delhi, Pp 346347.

IDF, 2014. The IDF Atlas, 6th edition [Internet document] URL www.idf.ogr/diabetesatlas. accessed on $14^{\text {th }}$ Sept. 2013.

IIPS, 2007. National Family Health Survey (NFHS-3), 2005-06: Volume I, Pp 305. International Institute for Population Sciences, Mumbai, India.

IS:SP-18 (Part XI), 1981. ISI Handbook for food analysis-Dairy Products. Bureau of Indian Standards, Manak Bhavan, New Delhi.

Kumar, N., 2006. Estimation and stability of saccharine in indigenous dairy products, Haryana, India. M.Sc. Thesis, National Dairy Research Institute, Karnal, India.

Mathur O. N., Bhattacharya, D. C., and Roy, N. K., 1985. Phirni: An Indian sweet dish. Indian Dairyman. 37(12): 575578.

Maske, R. D., 1997. Manufacture of safflower milk (dudh kusum), Maharashtra, India. M. Sc. Thesis, Marathwada Agricultural University, Parbhani, India.

Narwade S. G., Patil, G. R., Sontakke, A. T., and Patil, R. A., 2003. Preparation of kheer from safflower milk blended with buffalo milk. Indian Journal of Dairy Science. 56(4): 197-202.

Sarode, A. R., 2004. Standardization of a method for preparation of karadkheer and studies on its microbiological and chemical quality attributes, Maharashtra, India. Ph.D. Thesis, Swami Raman and Teerth Marathwada University, Nanded, India.

Snedecor, G. W., and Cochran, W. G., 1989. Statistical Methods. $8^{\text {th }}$ edition, Amsterdam.

Shetty, P., 2012. India's diabetes time bomb. Nature. 485: S14-S16.292.

Vairagade, A. S., Patil, M. R., Gawande, H. M., and Dhotre A. V., 2016. Stability of saccharine in low calorie carrot halwa. Asian Journal of Dairy and Food Research. 35(1): 41-49.

\section{How to cite this article:}

Walale, A.R., M.R. Patil and Gawande, H.M. 2019. Suitability of Saccharine for Preparation of Low Calorie Karadkheer. Int.J.Curr.Microbiol.App.Sci. 8(03): 1479-1492.

doi: https://doi.org/10.20546/ijcmas.2019.803.172 